\title{
Effect of initial periodontal therapy on sulcular/tongue sulfide level
} A pilot study*

\author{
Manabu Morita ${ }^{1}$ and Hom-Lay Wang ${ }^{2}$ \\ ${ }^{1}$ Department of Oral Health Science, \\ Graduate School of Dental Medicine, \\ Hokkaido, University, Sapporo, Japan, \\ 2Department of Periodontics/Prevention/ \\ Geriatrics, University of Michigan School of \\ Dentistry, Ann Arbor, MI, USA
}

\begin{abstract}
Morita M, Wang H-L. Effect of initial periodontal therapy on sulcular/tongue sulfide level. A pilot study. J Clin Periodontol 2002; 29: 844-847. (C) Blackwell Munksgaard 2002.
\end{abstract}

\begin{abstract}
Background : Volatile sulfur compounds (VSC), such as hydrogen sulfide, methyl mercaptan and dimethyl sulfide, are toxic metabolites produced by periodontal pathogens. These VSC are also released from the tongue dorsum. Currently, limited data are available on how periodontal treatments may affect sulcular/ tongue sulfide level. The aim of this study was to determine effect of initial therapy including oral hygiene instruction and scaling and root planing (SRP) on sulcular/tongue sulfide level.

Methods : Thirteen subjects diagnosed with chronic periodontitis and having three representative periodontal pocket depth (PD) strata in one quadrant $(\mathrm{PD} \leq$ $3.0 \mathrm{~mm}$ : healthy, $4.0 \mathrm{~mm} \leq \mathrm{PD} \leq 6.0 \mathrm{~mm}$ : moderate, and $\mathrm{PD} \geq 7.0 \mathrm{~mm}$ : severe disease sites) were selected. Clinical periodontal parameters were recorded at baseline and 3 weeks after completion of the initial therapy. The sulfide levels in three representative periodontal pockets $(\mathrm{pS})$ and on three parts (anterior, middle, and posterior) of the tongue dorsum (tS) were measured using a commercial sulfidemonitoring device.

Results : The pS levels of the three representative sites were reduced significantly following the initial therapy $(p<0.05)$. However, there was no significant reduction of the tS level in all three parts of the tongue.

Conclusions : The initial periodontal therapy such as oral hygiene and SRP reduces the sulcular sulfide level but not the tongue sulfide level. This suggests that sulcular sulfide level may be a possible indicator for assessing the outcome of initial periodontal treatment.
\end{abstract}

Key words: initial therapy; periodontal disease; sulcular sulfide level; tongue sulfide level

Accepted for publication 26 September 2001
Volatile sulfur compounds (VSC; hydrogen sulfide, methyl mercaptan and dimethyl sulfide) are produced by several periodontal pathogens (Persson et al. 1990, Kleinberg \& Westbay 1990, Ratcliff \& Johnson 1999). VSC accelerate periodontal tissue destruction (Rizzo 1967, Coil \& Tonzetich 1992, Ratcliff \& Johnson 1999). Rizzo (1967) and Coil \& Tonzetich (1992) reported a positive correlation between sulcular

*Disclaimers: The authors do not have any financial interests, either directly or indirectly, in the products listed in the study. sulfide level and the periodontal disease progression. This is in agreement with our recent finding, in which sulfide levels in periodontal pockets increased significantly in sites with increased radiographic bone loss (Morita \& Wang 2001a). Therefore, it has been suggested that sulcular sulfide level might be a potential indicator for detecting the severity of periodontal disease (Fine \& Mandel 1986). It has also been suggested that tongue dorsum is the potent reservoir of VSC in patients with periodontal disease (Yaegaki \& Sanada 1992). However, limited information is available on how initial periodontal therapy (e.g. oral hygiene improvement, scaling and root planing) influences VSC in periodontal pocket or on tongue dorsum.

Gas chromatography has often been used for detecting VSC (Coil \& Tonzetich 1992, Solis-Gaffar et al. 1980, Persson 1992). However, this technique suffers from some technical difficulties, and is costly and time-consuming. Recently, a portable sulfide monitor that provides real-time chairside information on sulcular sulfide level (pS) has been developed (Morita \& Wang 2001a, 
Table 1. Pocket depth (PD), clinical attachment level (CAL), bleeding index (BI),sulcular sulfide level $(\mathrm{pS})$ at baseline and after initial therapy (mean \pm SD)

\begin{tabular}{lllll}
\hline Site & Index & Baseline & Post -SRP & $p$ \\
\hline Healthy & PD & $2.92 \pm 0.28$ & $2.46 \pm 0.52$ & 0.008 \\
$(\mathrm{~mm})$ & CAL & $2.77 \pm 0.44$ & $2.54 \pm 0.52$ & NS \\
& BI & $0.31 \pm 0.48$ & 0.00 & 0.040 \\
Moderate & pS & $0.19 \pm 0.25$ & $0.04 \pm 0.14$ & 0.040 \\
$(\mathrm{~mm})$ & PD & $4.39 \pm 0.51$ & $3.62 \pm 0.51$ & $<0.001$ \\
& CAL & $4.31 \pm 0.63$ & $3.92 \pm 0.64$ & NS \\
& BI & $1.54 \pm 0.97$ & $0.23 \pm 0.44$ & 0.001 \\
Severeals & pS & $0.81 \pm 0.78$ & $0.15 \pm 0.32$ & 0.003 \\
$(7 \mathrm{~mm})$ & PD & $7.23 \pm 0.44$ & $5.50 \pm 0.97$ & $<0.001$ \\
& CAL & $7.16 \pm 0.99$ & $6.08 \pm 1.44$ & $<0.001$ \\
& BI & $2.31 \pm 1.11$ & $1.00 \pm 0.71$ & 0.005 \\
& pS & $1.50 \pm 0.74$ & $0.15 \pm 0.24$ & $<0.001$ \\
\hline
\end{tabular}

NS, Not significant.

2001b). In addition, the sulfide levels of anterior, middle and posterior parts of the tongue (tS) were also assessed quantitatively with the newly developed tongue sulfide probe connected to the portable sulfide monitor (Morita et al. 2001). Therefore, the aim of this study was to determine the effect of initial periodontal therapy on $\mathrm{pS}$ or $\mathrm{tS}$ level using the sulfide monitor.

\section{Material and methods} Study population and examiner calibration

After the Institutional Review Board of the University of Michigan approved the study protocol, 15 subjects were recruited from Graduate Periodontics at the University of Michigan School of Dentistry. Subject inclusion criteria were as follows: 1) adult males or females older than 20 years of age and 2) having chronic periodontitis with three representative periodontal pocket depth (PD) strata in one quadrant, $\mathrm{PD} \leq 3.0$ $\mathrm{mm}$ : healthy, $4.0 \mathrm{~mm} \leq \mathrm{PD} \leq 6.0 \mathrm{~mm}$ : moderate, and $\mathrm{PD} \geq 7.0 \mathrm{~mm}$ : severe disease sites. Exclusion criteria included 1) current smokers; 2) subjects taking any antibiotics within the last 3 months; 3 ) subjects with evidence of any systemic diseases; and 4) subjects who were pregnant or lactating.

One examiner (M.M.) was calibrated prior to the study and made all measurements during the course of the study to reduce intraexaminer error and to establish reliability and consistency. The intraexaminer agreements of PD, CAL, and $\mathrm{pS}$ were $0.96,0.95$, and 0.95 , respectively, using the Pearson correlation test, when 30 periodontal pockets were randomly selected from two patients and examined on two separate occasions.

\section{Periodontal examination}

Participants were given initial periodontal therapy including instruction in oral hygiene measures and received full mouth scaling and root planing (SRP) under local anesthesia. The SRP treatments were completed within 4 weeks. Data were collected at baseline (1-2 weeks prior to the onset of initial therapy) and 3 weeks after the completion of full mouth SRP. No antibiotic treatment was given during the study period.

The periodontal examination included PD, clinical attachment level (CAL), and bleeding index (BI) (Barnett et al. 1980) for three representative sites. PD and CAL were determined using the standard UNC (University of North Carolina) probe (read to $1 \mathrm{~mm}$ ). BI was judged as follows; 0: no bleeding, 1: bleeding between 3 and 30 s, 2: bleeding within $2 \mathrm{~s}$, and 3 : bleeding immediately upon probe placement.

\section{Sulcular and tongue sulfide level}

The sulfide levels in periodontal pocket (pS) and on tongue dorsum (tS) were measured using a commercial sulfidemonitoring device (Diamond Probe/ Perio $2000^{\circledR}$, Ann Arbor, MI, USA). The $\mathrm{pS}$ levels were evaluated in the three sites with representative probing pocket depth $(\leq 3 \mathrm{~mm}, 4-6 \mathrm{~mm}, \geq 7$ $\mathrm{mm}$ ). The tS levels were measured at the anterior, middle, and posterior part of tongue dorsum. The device consists of an electric control unit and a probe for pS (Morita \& Wang 2001a, 2001b) or for tS measurement (Morita et al. 2001). The electronic control unit reports the sulfide level in a digital score ranging 0.0 (undetectable sulfide; less than $10^{-7} \mathrm{M}$ of sulfide) to 5.0 (more than or equal to $10^{-2} \mathrm{M}$ of sulfide) in increments of 0.5 . This digital score, $\mathrm{pS}$ (or tS), is defined by $(\mathrm{pS}=7+\log \mathrm{S}$ ), where $\mathrm{S}$ is the molar concentration of sulfide in an 'equivalent model sulcus fluid'.

\section{Statistical analysis}

A power calculation was performed to determine the sample size required. The minimum of detecting difference of pocket depth between pre- and posttreatment status was set at 1.0 and the standard deviation of the measurements at $0.7 \mathrm{~mm}$ (Ong et al. 1998). A minimum of nine patients were required to allow a $95 \%$ chance of detecting a statistically significant difference with $\alpha$ set at 0.05 and the power of the study set at $95 \%$. Data were analyzed using the paired $t$-test for comparison between baseline and after initial periodontal therapy using the site as an experimental unit. Spearman's correlation coefficient was calculated between the degree of clinical improvements and the degree of changes in sulfide levels. Data were analyzed using the paired $t$-test for comparison between baseline and after the periodontal initial therapy. SAS $6.12^{\circledR}$ (SAS Institute, Cary, NC, USA) was used for all analyses.

\section{Results}

A total of 13 patients completed the study. Two individuals did not return for the follow-up visit and were therefore not included in the data analysis. Table 1 lists the change of periodontal parameters in the three representative sites. PD and BI of the three representative sites were significantly $(p<0.05)$

Table 2. Frequency distribution of sites with detectable sulcular sulfide (pS) level at baseline and after initial periodontal therapy

\begin{tabular}{lll}
\hline $\begin{array}{l}\text { pS level } \\
\text { (score) }\end{array}$ & $\begin{array}{l}\text { Baseline } \\
\text { (sites) }\end{array}$ & $\begin{array}{l}\text { After therapy } \\
\text { (sites) }\end{array}$ \\
\hline 0 & 12 & 31 \\
0.5 & 12 & 7 \\
1.0 & 2 & 1 \\
1.5 & 5 & 0 \\
2.0 & 6 & 0 \\
2.5 & 2 & 0 \\
\hline
\end{tabular}


Table 3. Tongue sulfide level (tS) at baseline and after initial therapy (mean \pm SD)

\begin{tabular}{llll}
\hline Part & Baseline & Post-treatment & $p$ \\
\hline Anterior & $0.04 \pm 0.14$ & $0.00 \pm 0.00$ & NS \\
Middle & $0.19 \pm 0.33$ & $0.04 \pm 0.14$ & NS \\
Posterior & $0.42 \pm 0.57$ & $0.27 \pm 0.33$ & NS \\
\hline
\end{tabular}

NS, Not significant.

improved after the initial therapy. The $\mathrm{pS}$ level of all representative disease sites was also reduced significantly $(p<$ $0.05)$.

Table 2 gives the distribution of $\mathrm{pS}$ at baseline and after initial periodontal therapy. The $\mathrm{pS}$ level ranged from 0 to 2.5 at baseline, and from 0 to 1.0 following therapy. Twenty-seven sites showed detectable pS $(>0)$ at baseline and only eight sites after therapy. Spearman's correlation coefficients between the degree of $\mathrm{pS}$ level and pocket depth, clinical attachment level and bleeding index improvement were 0.333 , 0.422 , and 0.639 , respectively $(p<0.05)$.

The tS level on the three parts of the tongue dorsum decreased following the initial periodontal therapy. However, the difference was not statistically significant (Table 3 ).

\section{Discussion}

Volatile sulfur compounds (VSC) are produced as a result of microbial putrefaction of food debris, cells, saliva, and blood within the oral cavity (Kleinberg \& Westbay 1990, Ratcliff \& Johnson 1999). Oral microbes, especially gram-negative bacteria, are the primary pathogens responsible for VSC production and VSC is the main course of oral malodor (Persson et al. 1990, Persson 1992). Areas where food is trapped and stagnated have potential to generate oral malodor. Recently, the dorsal surface of the tongue has been identified as the primary source of oral malodor in both periodontally diseased and healthy individuals (Bosy et al. 1994). The SRP is one of the effective techniques used in the clinic to reduce these microbes (Quirynen et al. 1998). However, the effect of SRP on sulcular/tongue sulfide level and oral malodor remains unknown.

Results from this study showed the $\mathrm{pS}$ level of all representative disease sites decreased significantly $(p<0.05)$ after the initial periodontal therapy. This finding suggests that periodontal pathogens in periodontal pockets may be re- duced/eradicated through initial periodontal therapy such as oral hygiene and SRP; thereby lowering the capacity of producing VSC in periodontal sulcus. This is in agreement with the observation made by Kleinberg \& Westbay (1990) and our previous results (Morita \& Wang 2001a). This further supports the hypothesis proposed by Fine \& Mandel (1986), who suggested that hydrogen sulfide generated by causative bacteria in periodontal disease might be an indicator for initiation or progression of periodontal disease. Since the pS level reduced after mechanical therapy, it may also serve as a useful tool for assessing response of initial periodontal therapy.

The tS level on the three parts of the tongue dorsum decreased following the initial periodontal therapy, although the difference was not statistically significant. This can be explained by an indirect effect from the oral hygiene and mechanical therapy. The initial periodontal therapy would reduce/eradicate these bacteria, hence reducing possible bacterial colonization. However, some periodontopathic bacteria originating from periodontal pockets may migrate to and relocate in the tongue. This is supported by Bollen et al. (1998). They compared the number of colony-forming units (CFU) on the tongue dorsum in the periodontal patients who received one-stage full-mouth disinfection (test group) and those who received fractionated periodontal therapy (control group). As a result, the number of Porphyromonas and Prevotella species was significantly reduced only in the test group. In addition, Quirynen et al. (1998) indicated that conventional periodontal treatment combined with onestage full-mouth disinfection using chlorhexidine resulted in significantly more reduction in oral malodor than conventional treatment only. These findings imply that oral malodor may reoccur due to site re-infection. When the full-mouth disinfection is not done, the tongue may act as a reservoir for VSC-producing pathogens. As shown in this study, the posterior part of the tongue produced higher tS than anterior and middle portions. This could be explained by the lack of cleansing function in the dorsal one-third of the tongue due to its close contact with the soft palate (Morita et al. 2001). Therefore, more efficient mechanical and chemical cleansing of the whole tongue dorsum surface may be essential for management of patients with oral malodor. Further study in this area is certainly required.

Limitations of this study include short duration and small sample size. As demonstrated in Table 1, clinical attachment levels in shallow and moderate sites were reduced following the initial periodontal therapy, but this reduction did not reach the significance level. This may be because of the sample size used in this study; a larger sample size might show a greater difference. In addition, further evidence is needed to support the use of total $\mathrm{pS}$ level as an indicator for evaluating treatment effect. Hence, further studies of longer duration, with larger sample sizes and more controlled selection are needed.

In summary, initial periodontal therapy such as oral hygiene and SRP reduces the sulcular sulfide level but not the tongue sulfide level. This suggests that sulcular sulfide level may be a possible indicator for assessing the outcome of initial periodontal treatment. Future study with larger sample size and longer follow-up is needed to either confirm or reject this initial finding.

\section{Acknowledgments}

The authors thank Dr. William Giannobile for his assistance in the preparation of this manuscript.

This study was supported in part by Diamond General Development Corp., Ann Arbor, MI, USA.

\section{Zusammenfassung}

Wirkung einer anfänglichen parodontalen Therapie auf Sulfidspiegel in Sulci bzw. in der Zunge. Eine Pilot-Studie.

Hintergründe: Flüchtige Schwefelverbindungen (VSC; volatile sulphur compounds) wie Wasserstoffsulfid, Methylmercaptan und Dimethylsulfid sind toxische Metaboliten, die durch parodontale Pathogene produziert werden. Diese VSC werden ebenso aus dem Zungenrücken freigesetzt. Es stehen derzeit nur begrenzt Daten zur Frage zur Verfügung, wie parodontale Behandlungen die Sulfidspiegel von Sulci oder der Zunge beeinflussen. Das Ziel der vorliegenden Studie war die Bestimmung des Effekts einer anfänglichen Therapie mit Beteiligung von Mundhygieneanleitung, Scaling und Wurzelglätten (SRP scaling and root planing) auf die Sulfidspiegel von Sulci und der Zunge.

Methodik: Dreizehn mit chronischer Parodontitis diagnostizierte Probanden mit dre repräsentativen Strata parodontaler Taschentiefe (PD; pocket depth) in einem Quadran- 
ten $(\mathrm{PD} \leq 3,0 \mathrm{~mm}$ : gesunde, $4,0 \mathrm{~mm} \leq \mathrm{PD} \leq$ 6,0 mm: mässige, und $\mathrm{PD} \geq 7,0 \mathrm{~mm}$ schwerwiegende Erkrankungsstellen) wurden ausgewählt. Die klinischen parodontalen Parameter wurden zu Baseline und 3 Wochen nach Beendigung der anfänglichen Therapie aufgezeichnet. Die Sulfidspiegel in drei repräsentativen parodontalen Taschen $(\mathrm{pS})$ und an drei Teilen (am anterioren, mittleren und posterioren) des Zungenrückens (tS) wurden mit Hilfe eines kommerziell erhältlichen Sulfid-Messgeräts gemessen.

Ergebnisse: Die pS-Spiegel der drei repräsentativen Stellen erwiesen sich nach der anfänglichen Therapie als signifikant reduziert $(\mathrm{p}<$ $0.05)$. Es konnte jedoch keine signifikante Reduktion des tS-Spiegels in allen drei Teilen des Zungenrückens nachgewiesen werden. Schlussfolgerung: Die anfängliche parodontale Therapie wie z. B. Mundhygienemassnahmen und SRP reduzieren den Sulcus-Sulfidspiegel, jedoch nicht den Sulfidspiegel der Zunge. Dies legt den Schluss nahe, dass die Sulcus-Sulfidspiegel als potentieller Indikator für die Bestimmung des Ergebnisses einer anfänglichen parodontalen Behandlung in Betracht gezogen werden könnte.

Kennworte: parodontale Erkrankung, anfängliche Therapie, Sulcus-Sulfidspiegel, Sulfidspiegel der Zunge

\section{Résumé}

Effet d'une thérapie parodontale initiale sur le niveau de sulfure sillon/langue: étude pilote Origine: Les composés sulfurés volatiles (volatile sulfur compounds, VSC) tels le sulfure d'hydrogène, le méthylmercaptan et le diméthylsulfure sont des métabolites toxiques produits par les pathogènes parodontaux. Ces VSC sont également libérés au niveau du dos de la langue. Les données existantes à l'heure actuelle sur la façon dont les traitements parodontaux affecteraient le niveau de sulfure sillon/langue sont limitées. Le but de cette étude était de déterminer l'effet d'une thérapie initiale sur le niveau de sulfure sillon/langue, cette thérapie comprenant un enseignement de l'hygiène bucco-dentaire ainsi qu'un détartrage et un surfaçage radiculaire ( $\mathrm{sca}$ ling and root planing, SRP).

Méthodes: Treize sujets chez qui une parodontite chronique a été diagnostiquée et ayant trois strates représentatives de profondeur de poche parodontale (pocket depth, $\mathrm{PD}$ ) dans un quadrant (sites sains: $\mathrm{PD} \leq 3,0$ $\mathrm{mm}$; sites à maladie modérée: $4,0 \mathrm{~mm} \leq \mathrm{PD}$ $\leq 6,0 \mathrm{~mm}$; sites à maladie sévère: $\mathrm{PD} \leq 7,0$ $\mathrm{mm}$ ) ont été sélectionnés. Les paramètres pa- rodontaux cliniques ont été enregistrés à la base puis trois semaines après achèvement de la thérapie initiale. Les niveaux de sulfure dans trois poches parodontales représentatives $(\mathrm{pS})$ et sur trois régions (antérieure, médiane et postérieure) du dos de la langue (tS) ont été mesurés à l'aide d'un appareil commercial de détection du sulfure.

Résultats: Les niveaux pS des trois sites représentatifs ont baissé de façon significative suite à la thérapie initiale $(\mathrm{p}<0,05)$. Il n'y avait toutefois pas de réduction significative $\mathrm{du}$ niveau tS dans les trois régions de la langue.

Conclusions: Une thérapie parodontale initiale, comme un enseignement de l'hygiène bucco-dentaire et un SRP, réduit le niveau de sulfure au niveau du sillon mais pas de la langue. Ceci suggère que le niveau de sulfure du sillon pourrait être considéré comme un indicateur potentiel pour évaluer le résultat du traitement parodontal initial.

Mots clés: Parodontite; thérapie initiale; niveau de sulfure du sillon; niveau de sulfure de la langue tongue.

\section{References}

Barnett, M., Ciancio, S. \& Mather, M. (1980) The modified papillary bleeding index: Comparison with Gingival Index during the resolution of gingivitis. Journal of Preventive Dentistry 6, 135-138.

Bollen, C. M. L., Mongardini, C., Papaioannou, W., van Steenberghe, D. \& Quirynen, M. (1998) The effect of a one-stage fullmouth disinfection on different intra-oral niches. Clinical and microbiological observations. Journal of Clinical Periodontology 25, 56-66.

Bosy, A., Kulkarni, G. V., Rosenberg, M. \& McCulloch, C. A. G. (1994) Relationship of oral malodor to periodontitis: evidence of independence in discrete subpopulations. Journal of Periodontology 65, 37-46.

Coil, J. M. \& Tonzetich, J. (1992) Characterization of volatile sulphur compounds production at individual gingival crevicular sites in humans. Journal of Clinical Dentistry 3, 97-103.

Fine, D. H. \& Mandel, I. D. (1986) Indicators of periodontal disease activity: an evaluation. Journal of Clinical Periodontology 13, 533-546.

Kleinberg, I. \& Westbay, G. (1990) Oral malodor. Critical Review of Oral Biology and Medicine 1, 247-259.

Morita, M., Musinski, D. L. \& Wang, H.L. (2001) Assessment of newly developed tongue sulfide probe for detecting oral ma- lodor. Journal of Clinical Periodontology 28, 494-496.

Morita, M. \& Wang, H. L. (2001a) Relationship of sulcular sulfide level to severity of periodontal disease and BANA Test. Journal of Periodontology 72, 74-78.

Morita, M. \& Wang, H. L. (2001b) Relationship between sulcular sulfide level and oral malodor in subjects with periodontal disease. Journal of Periodontology 72, 79-84.

Ong, M. M. A., et al. (1998) Evaluation of a bioactive glass alloplast in treating periodontal intrabony defects. Journal of Periodontology 69, 1346-1354.

Persson, S. (1992) Hydrogen sulfide and methyl mercaptan in periodontal pockets. Oral Microbiology and Immunology 7, 378-379.

Persson, S., Edlund, M. B., Claesson, R. \& Carlsson, J. (1990) The formation of hydrogen sulfide and methyl mercaptan by oral bacteria. Oral Microbiology and Immunology 5, 195-201.

Quirynen, M., Mongardini, C. \& van Steenberghe, D. (1998) The effect of a 1-stage full-mouth disinfection on oral malodor and microbial colonization of the tongue in periodontitis patients. A pilot study. Journal of Periodontology 69, 374-382.

Ratcliff, P. A. \& Johnson, P. W. (1999) The relationship between oral malodor, gingivitis, and periodontitis. A review. Journal of Periodontology 70, 485-489.

Rizzo, A. A. (1967) The possible role of hydrogen sulfide in human periodontal disease. I. Hydrogen sulfide production in periodontal pockets. Periodontics 5, 233 236.

Solis-Gaffar, M. C., Rustogi, K. N. \& Gaffar, A. (1980) Hydrogen sulfide production from gingival crevicular fluid. Journal of Periodontology 51, 603-606.

Yaegaki, K. \& Sanada, K. (1992) Volatile sulfur compounds in mouth air from clinically healthy subjects and patients with periodontal disease. Journal of Periodontal Research 27, 233-238.

Address:

Hom-Lay Wang

Department of Periodontics/Prevention/

Geriatrics

University of Michigan School of Dentistry

1011 North University Avenue

Ann Arbor, Michigan 48109-1078

USA

Tel: + 17437633383

Fax: + 17439360374

e-mail: address:homlay@umich.edu 